\title{
Annotatie
}

\section{Onderzoeksplicht of zorgvuldigheidsplicht bij de Wet Markt en Overheid? Het CBb verleent park-assist aan gemeenten}

\author{
Rb. Rotterdam 21 september 2017, ECLI:NL:RBROT:2017:7170; Rb. Rotterdam 22 maart \\ 2018, ECLI:NL:RBROT:2018:2123; Rb. Rotterdam 22 maart 2018, ECLI:NL:RBROT: \\ 2018:2119; CBb 18 december 2018, ECLI:NL:CBB:2018:660
}

Jasper Sluijs*

\section{Inleiding}

Deze annotatie bespreekt een aantal gerelateerde uitspraken van de Rechtbank Rotterdam en het College van Beroep voor het Bedrijfsleven $(\mathrm{CBb})$. In gezamenlijkheid geven deze uitspraken inzicht in de beoordelingsruimte van bestuursorganen om hun economische activiteiten op basis van het algemeen belang uit te zonderen van de Wet Markt en Overheid (Wet M\&O).

De Wet Markt en Overheid, oftewel hoofdstuk 4b van de Mededingingswet $(\mathrm{Mw})$, reguleert bestuursorganen die economische activiteiten ontplooien. Om een zo gelijk mogelijk speelveld tussen overheidsbedrijven en marktpartijen na te streven bevat deze wet vier gedragsregels voor overheden, waaronder een verplichting tot het doorrekenen van minimaal de integrale kostprijs. ${ }^{1}$ Bestuursorganen kunnen echter besluiten dat een specifieke economische activiteit plaatsvindt in het algemeen

Dr. J.P. Sluijs is universitair docent aan de vakgroep economisch publiekrecht van de Universiteit Utrecht. De auteur dankt Willem Janssen voor behulpzaam commentaar op een eerdere versie van deze annotatie, en Gijs van Midden voor waardevolle discussies over Wet M\&O-jurisprudentie.

1. Art. $25 \mathrm{i} \mathrm{Mw}$. belang; ${ }^{2}$ in dat geval zijn de vier gedragsregels van de Wet $\mathrm{M} \& \mathrm{O}$ niet meer van toepassing.

Deze uitzondering lijkt het meest betwiste onderdeel van de Wet $\mathrm{M} \& \mathrm{O}$, getuige het aanzienlijke aantal beroepsprocedures bij met name de Rechtbank Rotterdam. ${ }^{3}$ Ook in commentaar is de algemeenbelanguitzondering veelvuldig besproken. ${ }^{4}$

Met de laatste uitspraak van het $\mathrm{CBb}$ van 18 december 2018 is er nu aanleiding om de reikwijdte van artikel $25 \mathrm{~h}$ lid 5-6 Mw onder de loep te nemen. Dit temeer omdat richting vanuit de wetgever ontbreekt: ondanks voornemens daartoe in het huidige regeerakkoord, ${ }^{5}$ is er tot op heden geen wetsvoorstel in behandeling met een scherpere definitie van de algemeenbelanguitzondering.

2. Art. 25h lid 5-6 Mw

3. Zie de hier besproken beroepen, alsmede de procedures $\mathrm{Rb}$. Rotterdam 31 augustus 2017, ECLI:NL:RBROT:2017:6538, AB 2017/432 (Veenendaal); Rb. Rotterdam 28 juni 2018, ECLI:NL:RBROT:2018:5147 (Hilversum); Rb. Rotterdam 26 januari 2017, ECLI:NL:RBROT:2017:631 (Jachthaven Wolderwijd/Zeewolde); Rb. Rotterdam 2 november 2017, ECLI:NL:RBROT:2017:8253 (Sportcentrum Hulsberg/Nuth); Rb. Rotterdam 22 maart 2018, ECLI:NL:RBROT:2018:2244 (Camperplaats Stadskanaal).

4. Zie, bijvoorbeeld, G.J. van Midden, JutD 2018/0061 (afl. 9); J. Eck en F.G.D. Pasaribu, Bb 2015/61 (afl. 18, p. 214-216); G.J. van Midden, JutD 2015/3 (afl. 1, p. 10-13).

5. Vertrouwen in de toekomst, Regeerakkoord 2017-2021 VVD, CDA, D66 en ChristenUnie, p. 34 
Deze annotatie bespreekt en becommentarieert daarom de recente ontwikkeling in jurisprudentie, met aandacht voor drie uitspraken van de Rechtbank Rotterdam en een uitspraak in hoger beroep betreffende een van die zaken voor het $\mathrm{CBb}$.

\section{Feiten}

Deze uitspraken hebben alle betrekking op lokale markten voor betaald parkeren. Eiseres is steeds Q-Park, een commerciële exploitant van parkeergelegenheden. Verweerders zijn respectievelijk de raad van de gemeenten Hengelo, ${ }^{6}$ Emmen ${ }^{7}$ en 's-Hertogenbosch. ${ }^{8}$ Deze gemeenten exploiteren zelf een 'publieke' parkeergarage. De gemeente Hengelo is appellant in de hogerberoepszaak voor het $\mathrm{Cbb}$.

De gemeenten stelden in de periode 2014-2016 algemeenbelangbesluiten vast waarin zij de exploitatie van hun eigen parkeerterreinen uitzonderden van de toepassing van de Wet Markt en Overheid.

De drie gemeenten streefden specifiek een uitzondering na van artikel $25 \mathrm{i} \mathrm{Mw}$, dat bestuursorganen die economische activiteiten ontwikkelen, verplicht minimaal de integrale kostprijs van een product of dienst in rekening te brengen aan afnemers. ${ }^{9}$ Op basis van deze uitzondering wilden de gemeenten op door hen beheerde parkeerterreinen een parkeertarief onder de kostprijs aanbieden. In Hengelo was dit gemeentelijke parkeertarief 0,50 euro per uur goedkoper dan het tarief van Q-Park en in Emmen 0,25 euro per uur goedkoper. In 's-Hertogenbosch is het precieze verschil tussen het gemeentelijke en het commerciële parkeertarief niet vermeld in de uitspraak. Hier heeft de gemeente voor parkeergelegenheid op transferia buiten het stadscentrum het prijspeil van 2016 bevroren, waarvoor tot die tijd wel degelijk ten minste de integrale kostprijs in rekening werd gebracht. De beweegredenen van de gemeenten om parkeertarieven onder de kostprijs aan te bieden zijn verwant aan elkaar. In Hengelo streeft de gemeenteraad na dat bezoekers van een hotel en theater parkeren in de nabijgelegen parkeergarage, om hinderlijk foutparkeren en verkeersopstopping door rondrijdende auto's op zoek naar een parkeerplaats aan de straat te voorkomen. Naast deze 'regulering van parkeerstromen' stelt de gemeenteraad dat lagere parkeertarieven meer bezoekers naar de binnenstad zullen trekken. ${ }^{10}$

De gemeente Emmen relateert parkeerkosten aan de strategische doelstellingen van het gemeentelijke verkeer- en vervoersplan en bijbehorende beleidsdocumen-

6. Rb. Rotterdam 21 september 2017, ECLI:NL:RBROT:2017:7170 (Hengelo/Q-Park); zie ook CBb 18 december 2018, ECLI:NL:CBB:2018:660 (Hengelo/Q-Park).

7. Rb. Rotterdam 22 maart 2018, ECLI:NL:RBROT:2018:2123 (Emmen/ Q-Park).

8. Rb. Rotterdam 22 maart 2018, ECLI:NL:RBROT:2018:2119 ('s-Hertogenbosch/Q-Park).

9. De wijze van toerekening van de integrale kosten is vastgelegd in arts. 5-8 van het Besluit markt en overheid.

10. Hengelo/Q-Park, r.o. 2.4. ten. ${ }^{11}$ Hieruit volgt dat tarieven in gemeentelijke parkeergarages bewust goedkoper zijn dan die van straatparkeren, om het straatbeeld te verbeteren. De gemeenteraad stelt dat dergelijk reguleren van parkeerstromen en beperken van parkeeroverlast niet voldoende realiseerbaar is wanneer het wordt overgelaten aan de markt, mede gegeven de lage bezettingsgraad van de gemeentelijke parkeerterreinen. ${ }^{12}$

Ook in 's-Hertogenbosch zijn parkeerkosten onderdeel van gemeentelijk mobiliteitsbeleid. Op basis van de ruimtelijke structuurnota en de hieruit voortvloeiende 'koersnota hoofdinfrastructuur' stelt de gemeente dat de Bossche binnenstad de bestaande parkeervraag onvoldoende aankan. Bovendien streeft de gemeente een 'autoluwe' binnenstad na. ${ }^{13}$ Hieruit volgt het streven van de gemeenteraad om met parkeertariefdifferentiatie een betere spreiding van parkeerstromen te bewerkstelligen. Goedkopere tarieven, in combinatie met bus- en (leen)fietsvervoer, moeten het aantrekkelijker maken voor bezoekers om buiten de stad op transferia te parkeren. ${ }^{14}$

Eiseres Q-Park ging in alle drie de gemeenten in bezwaar tegen het vaststellingsbesluit waarmee de raad gemeentelijke parkeervoorzieningen via artikel $25 \mathrm{~h}$ lid 5 Mw buiten de Wet Markt en Overheid plaatste. De gemeenten verklaarden deze bezwaren ongegrond, waarop Q-Park beroep aantekende bij de bevoegde rechtbank, te Rotterdam. Wat betreft het procesverloop in Emmen is het voorts vermeldenswaardig dat de gemeentelijke commissie van advies voor bezwaarschriften had geadviseerd het vaststellingsbesluit te herroepen vanwege onzorgvuldige voorbereiding en een gebrek aan belangenafweging. De gemeente Emmen legde dit advies naast zich neer. In 's-Hertogenbosch werd de gemeente in gebreke gesteld vanwege het aanvankelijke uitblijven van een beslissing in de bezwaarprocedure. Het gaat hier dus om bestuursrechtelijke procedures tegen algemeenbelangbesluiten van de gemeentes en niet om een beroep van een gemeente tegen een handhavingsbesluit van de ACM.

\section{De uitspraken}

\section{Rechtbank Rotterdam}

De beroepen zijn alle behandeld door het team bestuursrecht 1 van de Rechtbank Rotterdam in vrijwel identieke samenstelling. De overwegingen van de rechtbank volgen een vergelijkbaar stramien.

\section{- Beoordelingsruimte}

De rechtbank begint haar beoordeling telkens met de constatering dat bestuursorganen beschikken over een 'zeer ruime beoordelingsmarge' in het vaststellen van algemeen belang in de procedure van artikel $25 \mathrm{~h} \mathrm{Mw}$.

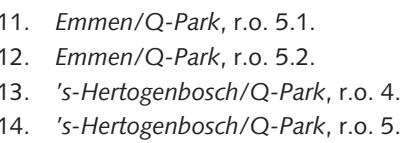


Hieruit volgt dat gerechtelijke toetsing met 'enige terughoudendheid' plaats dient te vinden. ${ }^{15}$ Met deze constatering baseert de rechtbank zich op een uitspraak in hoger beroep uit 2016, waarin het CBb zich voor het eerst uitliet over de algemeenbelanguitzondering van de Wet Markt en Overheid. ${ }^{16}$ Deze uitspraak van het $\mathrm{CBb}$ introduceerde, op basis van de wetsgeschiedenis van de Wet Markt en Overheid, dat voorafgaand aan een algemeenbelangbesluit een afweging plaats moest vinden tussen het (algemene) belang dat het besluit nastreeft, en het belang van derden dat door het besluit wordt getroffen. Uit die afweging kan vervolgens voortvloeien dat compensatie van schade nodig is die redelijkerwijs niet ten laste van derden hoort te komen. ${ }^{17}$

\section{- Zorgvuldige voorbereiding}

In de drie beroepszaken is de rechtbank relatief kort in haar beoordeling van de mate waarin de vereiste belangenafweging heeft plaatsgevonden ter voorbereiding op de vaststellingsbesluiten van de gemeenten. In het Hengelose en Bossche beroep stelt de rechtbank dat uit het procesdossier niet blijkt dat de gemeente kennis vergaard heeft over de af te wegen belangen, en dat er dus van uitgegaan mag worden dat deze afweging ook niet heeft plaatsgevonden bij de voorbereiding van het primaire besluit. ${ }^{18}$ In het beroep tegen de gemeente Emmen voegt de rechtbank aan een vergelijkbare constatering toe dat hoewel het de vraag is in hoeverre de belangen van Q-Park als derde in casu daadwerkelijk worden geschaad, dit niet onverlet laat dat de afweging zelf ontbreekt. ${ }^{19}$

Aanvullend merkt de rechtbank in alle drie de zaken echter op dat de te betrachten terughoudendheid niet wegneemt dat het vaststellingsbesluit van de gemeenten getoetst dient te worden aan de zorgvuldigheidseisen die de Algemene wet bestuursrecht (Awb) daaraan verbindt. In alle drie de beroepen concludeert de rechtbank dat de gemeenten niet aan deze zorgvuldigheidseisen hebben voldaan. ${ }^{20}$ Hierbij baseert de rechtbank zich met name op artikel 3:2 Awb (zorgvuldige voorbereiding), dat vereist dat een bestuursorgaan ter voorbereiding op een besluit 'de nodige kennis omtrent de relevante feiten en de af te wegen belangen' vergaart. ${ }^{21}$

In het Hengelose beroep merkt de rechtbank op dat gedegen onderbouwing van het gemeentelijke vaststellingsbesluit ontbreekt. De gemeente heeft volgens de rechtbank geen enkel onderzoek verricht naar het veronderstelde verband tussen parkeertarieven beneden kostprijs enerzijds, en anderzijds het beter kunnen reguleren van parkeerstromen, het voorkomen van parkeerover-

15. Hengelo/Q-Park, r.o. 4.1; Emmen/Q-Park, r.o. 7.1; 's-Hertogenbosch/ Q-Park, r.o. 7.1.

16. CBb 21 december 2016, ECLI:NL:CBB:2016:414, AB 2017/431, m.nt. P.C. Adriaanse en A.H.A. Mohammad, p. 2969

17. CBb 21 december 2016, ECLI:NL:CBB:2016:414, ro. 5.3.

18. Hengelo/Q-Park, r.o. 4.5; 's-Hertogenbosch/Q-Park, r.o. 7.5.

19. Emmen/Q-Park, r.o. 7.5.

20. Hengelo/Q-Park, r.o. 4.2; Emmen/Q-Park, r.o. 7.2; 's-Hertogenbosch/ Q-Park, r.o. 7.2.

21. Ter achtergrond, zie J.C.A. de Poorter, $T \& C A w b$, commentaar op art. 3:2 Awb. last, of stimuleren van bezoek aan de binnenstad. De gemeente gaat volgens de rechtbank niet verder dan het uitspreken van hoop en verwachting over in hoeverre parkeertarieven aan deze belangen een bijdrage leveren - zowel in het vaststellingsbesluit, als in de stellingen in beroep. ${ }^{22}$

Ook in het beroep tegen de gemeente Emmen stelt de rechtbank dat gedegen onderbouwing ontbreekt, in dit geval waarom parkeertarieven beneden kostprijs noodzakelijk zijn om straatparkeren te ontmoedigen. De gemeente is in het vaststellingsbesluit niet verder gekomen dan dat het aannemelijk is dat tarieven van ten minste kostprijs in parkeergarages tot een toename van straatparkeren zal leiden, en heeft pas na het vaststellingsbesluit daadwerkelijk onderzoek laten uitvoeren door een onafhankelijk bureau. Het betreffende onderzoek gaat echter niet in op de effecten van parkeertarieven op de bezettingsgraad van de parkeergarages. ${ }^{23}$

Het Bossche vaststellingsbesluit bevat volgens de rechtbank evenmin een gedegen onderbouwing tussen nagestreefde beleidsdoelen en parkeertarieven beneden kostprijs. De gemeente heeft immers niet onderzocht in hoeverre het mogelijk was ook met kostprijsgeoriënteerde tarieven de beleidsdoelstelling te bereiken van een betere spreiding van de parkeervraag. Daarnaast neemt de rechtbank in haar oordeel mee dat eerdere verhogingen van parkeertarieven op de transferia niet of nauwelijks effect hebben gehad op de bezetting. ${ }^{24}$

Op basis van de hierboven beschreven redenering verklaart de rechtbank de drie beroepen gegrond, vernietigt en herroept ze de primaire besluiten van de gemeenten en bepaalt dat de uitspraken in de plaats treden van de vernietigde besluiten. ${ }^{25}$

\section{$\mathrm{CBb}$}

Hengelo is in hoger beroep gegaan bij het $\mathrm{CBb}$. De gemeente voert twee gronden aan voor hoger beroep: (1) de rechtbank heeft ten onrechte het beroep van Q-Park gegrond verklaard, op basis van een te weinig terughoudende rechterlijke toetsing van het vaststellingsbesluit van de gemeente; ${ }^{26}$ (2) de rechtbank heeft het primaire besluit ten onrechte herroepen, waar de gemeente opgedragen had moeten worden het besluit te herstellen. ${ }^{27}$

\section{- Beoordelingsruimte}

Het $\mathrm{CBb}$ start zijn beoordeling van het geschil met een uiteenzetting van de grondslagen van de Wet Markt en Overheid, en de algemeenbelanguitzondering in het bijzonder. Op basis van de wetsgeschiedenis stelt het College dat een algemeenbelangbesluit bij uitstek een politieke aangelegenheid is, en daarom tot een 'aanzienlijke beoordelingsruimte' voor bestuursorganen leidt in

22. Hengelo/Q-Park, r.o. 4.3.

23. Emmen/Q-Park, r.o. 7.3.

24. 's-Hertogenbosch/Q-Park, r.o. 7.3.

25. Hengelo/Q-Park, r.o. 4.7; Emmen/Q-Park, r.o. 9; 's-Hertogenbosch/ Q-Park, r.o. 8 .

26. CBb 18 december 2018, ECLI:NL:CBB:2018:660, r.o. 3.1 (Hengelo/ Q-Park).

27. CBb Hengelo/Q-Park, r.o. 3.2 
het vaststellen van algemeen belang. ${ }^{28}$ Deze beoordelingsruimte is echter niet onbegrensd, maar dient in verhouding te blijven met het doel van hoofdstuk $4 \mathrm{~b} \mathrm{Mw}$, namelijk het bewerkstelligen van een gelijk speelveld tussen overheidsbedrijven en de private sector. In deze afweging tussen autonomie van bestuursorganen en het nastreven van een gelijk speelveld ligt volgens het $\mathrm{CBb}$ de kern van de afweging van belangen tussen algemeen belang en belangen van derden die voor een algemeenbelangbesluit van artikel $25 \mathrm{~h}$ lid 5-6 Mw noodzakelijk is. ${ }^{29}$ Het College expliciteert vervolgens de bestuursrechtelijke basis van de belangenafweging tussen algemeen belang en belangen van derden. Het beginsel van zorgvuldige voorbereiding uit artikel 3:2 Awb volgt volgens het College uit artikel 3:46 Awb, dat ziet op een deugdelijke motivering van een besluit. Een deugdelijke motivering inzake het vaststellen van algemeen belang dient dus plaats te vinden door het vergaren van kennis over de relevante feiten en de af te wegen belangen. ${ }^{30}$

- Voormaarden voor deugdelijke belangenafmeging

Hierop noemt het $\mathrm{CBb}$ drie cumulatieve voorwaarden, aan de hand waarvan moet worden getoetst of de belangenafweging deugdelijk heeft plaatsgevonden bij een algemeenbelangbesluit dat erop is gericht een bepaalde economische activiteit beneden de kostprijs aan te bieden. ${ }^{31}$ Het bestuursorgaan dient allereerst (1) voldoende kennis omtrent de relevante feiten en af te wegen belangen te vergaren. Vervolgens (2) moet het 'zich redelijkerwijs op het standpunt [hebben] kunnen stellen' dat met de economische activiteit in kwestie het algemeen belang is gediend. Dit gaat volgens het College in ieder geval niet op, wanneer het aanbieden van economische activiteiten beneden kostprijs niet noodzakelijk is om het algemeen belang te dienen. Deze noodzakelijkheid ontbreekt wanneer het algemeen belang ook wordt gediend als de economische activiteit niet beneden kostprijs wordt aangeboden, of wanneer het niet aannemelijk is dat marktpartijen met hun aanbod het algemeen belang niet kunnen dienen. Wanneer het bestuursorgaan aan deze tweede voorwaarde heeft voldaan, toetst de rechter ten slotte (3) of het bestuursorgaan in redelijkheid gebruik heeft gemaakt van zijn bevoegdheid tot het nemen van een algemeenbelangbesluit. Van dergelijke redelijkheid is bijvoorbeeld sprake wanneer de prijsstelling reflecteert dat het door het bestuursorgaan nagestreefde effect bereikt wordt, terwijl het nadeel voor betrokken ondernemingen zo veel mogelijk beperkt blijft. Ook een beperkte geldigheidsduur van het besluit of compensatie in geval van nadeel kan volgens het College getuigen van in redelijkheid toegepaste bevoegdheid.

In het betreffende geschil is volgens het College voldoende aangetoond dat het, gegeven de beleidsdoelen van de gemeente (reguleren van parkeerstromen, voorkomen van parkeeroverlast), wenselijk is dat er zich in

28. CBb Hengelo/Q-Park, r.o. 5.2

29. CBb Hengelo/Q-Park, r.o. 5.2.

30. CBb Hengelo/Q-Park, r.o. 5.3.

31. CBb Hengelo/Q-Park, r.o. 5.3. de nabijheid van het hotel en het theater een parkeergarage bevindt. ${ }^{32}$ Ook is er volgens het College een dermate groot verschil tussen het daadwerkelijke tarief in de gemeentelijke parkeergarage (1,90 euro per uur) en het door de gemeente overgelegde, en door het College goedgekeurde, tarief op basis van kostprijs (4,70 euro per uur), dat aannemelijk is dat parkeerders de gemeentelijke parkeergarage zouden mijden bij tarieven op basis van integrale kostprijs. ${ }^{33}$

De gemeente Hengelo heeft echter volgens het College verzaakt te onderzoeken in hoeverre marktpartijen konden voorzien in de parkeervraag rond hotel en theater op een manier die recht doet aan bovengenoemde beleidsdoelen. De gemeente heeft geen vergelijking gemaakt tussen de situatie waarin haar parkeergarage wel en niet operationeel is, heeft niet aangetoond dat bezoekers van hotel en theater in te beperkte mate gebruikmaken van de parkeergelegenheden van Q-Park, of dat er parkeeroverlast ontstaat wanneer bezoekers gebruikmaken van de parkeergelegenheden van Q-Park. Ook is niet aangetoond dat de capaciteit van Q-Park ontoereikend is voor bezoekers van hotel en theater. ${ }^{34}$

Het College concludeert daarom dat de gemeente niet voldoende kennis heeft vergaard over relevante feiten en af te wegen belangen (voorwaarde 1), en bevestigt hiermee de uitspraak van de rechtbank. Hiermee faalt grond 1 van het hoger beroep. ${ }^{35}$

\section{- $\quad$ Herstel besluit}

Inzake grond 2 bepaalt het College echter dat de rechtbank ten onrechte heeft vastgesteld dat de gebreken aan het Hengelose algemeenbelangbesluit niet meer hersteld konden worden. Naast zijn kritiek op het ontbreken van een motivering van de rechtbank in deze, stelt het College dat Hengelo überhaupt de gelegenheid had moeten krijgen om alsnog de kennis van relevante feiten en belangen te vergaren. ${ }^{36}$ Daarom draagt het College de gemeente op om binnen vier maanden een nieuw besluit te nemen op het oorspronkelijke bezwaar van Q-Park, met inachtneming van deze uitspraak van het College. Wanneer de gemeente vervolgens meent dat een algemeenbelangbesluit noodzakelijk blijft om parkeertarieven beneden kostprijs aan te bieden, dan zal het nadeel van Q-Park in kaart moeten worden gebracht, en nagegaan moeten worden in hoeverre Q-Park voor dit nadeel tegemoetgekomen moet worden. Deze tegemoetkoming kan bestaan uit tarieven die het nadeel van Q-Park zo veel mogelijk beperken, het verbinden van een termijn aan het besluit of het bieden van compensatie voor het nadeel dat redelijkerwijs niet ten laste van Q-Park moet blijven. ${ }^{37}$ 


\section{Commentaar}

Met de uitspraak in hoger beroep van het $\mathrm{CBb}$ van december 2018 volgt een nieuw hoofdstuk in het epos over de toepassing van de Wet Markt en Overheid op gemeentelijke parkeergelegenheden. Naast de drie voornoemde zaken heeft de Rechtbank Rotterdam ook verwante beroepsprocedures behandeld tussen Q-Park en respectievelijk de gemeenten Veenendaal en Hilversum. ${ }^{38}$ Q-Park heeft zich als activistische eiser opgesteld, met in eerste instantie als resultaat een reeks uitspraken van de Rechtbank Rotterdam die nadelig uitpakten voor de betreffende gemeenten. Het $\mathrm{CBb}$ heeft de balans tussen bestuursorganen en betrokken marktpartijen nu hersteld waar het gaat om de uitzondering van de verplichting tot het aanbieden van integrale kostprijs op grond van het algemeen belang. In wat volgt, ga ik nader in op de verschillende stappen van de door het $\mathrm{CBb}$ voorgeschreven toetsing.

\section{Achtergrond}

De uitzondering op grond van algemeen belang is al sinds de totstandkoming van de Wet Markt en Overheid controversieel. De uitzondering was in deze vorm niet voorzien in het oorspronkelijke wetsvoorstel, maar belandde na een amendement van de leden Ten Hoopen en Vos in de wet. ${ }^{39}$ Verdere duiding van deze uitzondering vanuit de wetgevende macht ontbreekt, al wordt wel stilgestaan bij de algemeenbelanguitzondering in de 'handreiking Wet Markt en Overheid' van het ministerie van Economische Zaken. Gemeenten hebben sindsdien veelvuldig gebruikgemaakt van de algemeenbelanguitzondering. De evaluatie van de Wet Markt en Overheid uit 2015 vermeldt dat meer dan 90 procent van de geënquêteerde gemeenten algemeenbelangbesluiten heeft vastgesteld. ${ }^{40}$

Uitgangspunt voor de 'parkeerberoepen' voor de Rechtbank Rotterdam is bovengenoemde uitspraak van het $\mathrm{CBb}$ uit 2016 betreffende sportaccommodaties in Zoetermeer. ${ }^{41}$ Deze uitspraak in hoger beroep ziet op de noodzaak van een afweging tussen algemeen belang enerzijds en de belangen van getroffen marktpartijen bij een algemeenbelangbesluit van een bestuursorgaan. ${ }^{42}$ Volgens het College dient de terughoudende rechterlijke

38. Zie Rb. Rotterdam 31 augustus 2017, ECLI:NL:RBROT:2017:6538, AB 2017/432, m.nt. P.C. Adriaanse en A.H.A. Mohammad (Veenendaal), en Besluit ACM d.d. 26 maart 2018 (Beslissing op bezwaar gemeente Veenendaal) en Rb. Rotterdam 28 juni 2018, ECLI:NL:RBROT: 2018:5147 (Hilversum).

39. Kamerstukken /I 2008/09, 31354, 32 (gewijzigd amendement-Ten Hoopen en Vos). In het oorspronkelijke wetsvoorstel voorzag de wetgever overigens ook in uitzonderingen op de verplichting tot in rekening brengen van integrale kosten, bijvoorbeeld bij de vervulling van het beheer van een dienst van algemeen economisch belang. Zie Kamerstukken // 2007/08, 31354, 2 (voorstel van wet aanpassing Mededingingswet ter invoering van gedragsregels voor de overheid), art. $25 \mathrm{i}$ lid 2 sub a.

40. Kamerstukken // 2015/16, 34487, 1 (Evaluatie Wet Mark ten Overheid).

41. CBb 21 december 2016, ECLI:NL:CBB:2016:414

42. CBb 21 december 2016, ECLI:NL:CBB:2016:414, r.o. 5.3 toetsing van een algemeenbelangbesluit zich op de deugdelijkheid van deze belangenafweging te richten. ${ }^{43}$

De Rechtbank Rotterdam heeft vervolgens, met deze $\mathrm{CBb}$-uitspraak in de hand, een aanzienlijk aantal zaken behandeld omtrent de algemeenbelanguitzondering van artikel 25h lid 5-6 Mw, waaronder de parkeerberoepen. ${ }^{44}$ Hierin is het opvallend dat de rechtbank in toenemende mate de uitspraak van het $\mathrm{CBb}$ ruim interpreteert. In de behandeling van het geschil tussen Q-Park en de gemeente Veenendaal introduceert de rechtbank dat een algemeenbelangbesluit aan de zorgvuldigheidseisen op grond van artikel 3:2 Awb moet voldoen, en besteedt ze aanzienlijk meer andacht an deze zorgvuldigheidseisen dan de belangenafweging die het $\mathrm{CBb}$ voorschrijft in het Zoetermeerse hoger beroep. Adriaanse en Mohammad hebben hier in hun annotatie van Veenendaal/Q-Park al bij stilgestaan. ${ }^{45}$

Onderzoeksplicht

In de drie hier besproken procedures lijkt vervolgens sprake te zijn van een doorontwikkeling van bestuursrechtelijke zorgvuldigheidseisen richting een onderzoeksplicht voor gemeenten. Wat betreft de Hengelose zaak beperkt de rechtbank zich nog tot het ontbreken van feitelijke onderbouwing: de gemeente heeft geen onderzoek gedaan om aan te tonen dat er daadwerkelijk een effect bestaat tussen parkeertarieven beneden kostprijs en gestelde beleidsdoelen. In de Emmense beroepsprocedure stelt de rechtbank vervolgens dat de gemeente verder dan het niveau van annemelijkheid dient te onderzoeken of bezoekers daadwerkelijk zouden uitwijken naar straatparkeren bij parkeertarieven boven kostprijs. Ten slotte, in de zaak 's-Hertogenbosch dient de gemeente te onderzoeken wat de effecten van het wél in rekening brengen van integrale kosten voor parkeertarieven zouden zijn, en of de gestelde beleidsdoelen bij het niet in rekening brengen van integrale kosten ook behaald kunnen worden.

Merk op dat hiermee het formele vereiste van zorgvuldige voorbereiding sluipenderwijs ook een materiële component heeft gekregen: de rechtbank lijkt niet alleen te toetsen of er sprake is van zorgvuldige voorbereiding in de vorm van onderzoek, maar ook hoe een bestuursorgaan een onderzoek dient uit te voeren. In de Emmense en Bossche uitspraken lijkt de rechtbank zogenoemd 'elasticiteitsonderzoek' te vereisen, waarin het verband tussen verschillende prijsniveaus en consumentenvraag onderzocht wordt. Dergelijk onderzoek bepaalt de betalingsbereidheid van consumenten: welk maximumparkeertarief zijn consumenten bereid om te betalen voordat zij besluiten niet meer gebruik te maken van betaalde parkeergelegenheden?

43. CBb 21 december 2016, ECLI:NL:CBB:2016:414, r.o. 5.4

44. Zie hiernaast, bijvoorbeeld, Rb. Rotterdam 26 januari 2017, ECLI:NL:RBROT:2017:631 (Jachthaven Wolderwijd/Zeewolde); Rb. Rotterdam 2 november 2017, ECLI:NL:RBROT:2017:8253 (Sportcentrum Hulsberg/Nuth); Rb. Rotterdam 22 maart 2018, ECLI:NL: RBROT:2018:2244 (Camperplaats Stadskanaal).

45. Rb. Rotterdam 31 augustus 2017, ECLI:NL:RBROT:2017:6538, $A B$ 2017/432, m.nt. P.C. Adriaanse en A.H.A. Mohammad (Veenendaal). 
Inzichten uit vervoerseconomie en bestuursrecht In de vervoerseconomie blijkt vraagelasticiteit van betaald parkeren zeer uitgebreid onderzocht te zijn. ${ }^{46}$ Verkeerskundig kennisplatform CROW concludeert echter in een meta-analyse van dergelijke studies dat prijselasticiteit bij betaald parkeren van een groot aantal factoren afhankelijk kan zijn. Denk hierbij (onder andere) aan het doel van parkeren (recreatief of zakelijk), het tijdstip, de dag van de week, de duur van parkeren of het moment van betalen (vooraf of achteraf). Hiernaast laat stated preference-onderzoek op basis van verwachte effecten andere resultaten zien dan revealed preferenceonderzoek naar geobserveerde effecten. ${ }^{47}$

Gegeven de ambigue resultaten uit de verkeerseconomische literatuur, lijken de vereisten die de Rechtbank Rotterdam stelt aan onderzoek naar de gedragseffecten van parkeertarieven op zijn minst ambitieus te zijn. Om een eenduidig antwoord te krijgen op de vraag in hoeverre parkeertarieven boven of beneden kostprijs een aantoonbaar effect op beleidsdoelen als spreiding hebben, zou een multifactoranalyse noodzakelijk zijn die in de wetenschappelijke literatuur thans nog niet vertoond lijkt te zijn.

Met een dergelijke standaard van onderzoek kan een onderzoeksplicht de 'zeer ruime beoordelingsruimte' kannibaliseren die de rechtbank een bestuursorgaan toedicht om te bepalen of zijn economische activiteit al dan niet plaatsvindt in het algemeen belang. Wanneer een gemeente op basis van uitgebreid onderzoek zonder een basis van wetenschappelijke consensus haar vaststellingsbesluit moet motiveren, beperkt dat inherent de beoordelingsruimte van de gemeente in het vaststellen van algemeen belang.

Het is bovendien de vraag of een zo vergaande onderzoeksplicht aansluit bij wat artikel 3:2 Awb daadwerkelijk vereist. De Poorter merkt op dat hoewel artikel 3:2 Awb de rechter een flexibel instrument geeft om de nauwkeurigheid, omvang en diepgang in de voorbereiding van een besluit te toetsen, kennisvergaring niet verder hoeft te gaan dan voor het specifieke besluit noodzakelijk is. ${ }^{48}$ Artikel 3:2 Awb heeft daarom vooral aanleiding gegeven besluiten te vernietigen waarin belangen niet deugdelijk zijn afgewogen of het bestuursorgaan

46. Zie, bijvoorbeeld, G. Albert en D. Mahalel, 'Congestion tolls and parking fees: A comparison of the potential effect on travel behavior' Transport Policy 2006, nr. 6, p. 496-502; D. Hensher en J. King, 'Parking demand and responsiveness to supply, pricing and location in the Sydney central business district', Transportation Research Part A: Policy and Practice 2001, nr. 3, p. 177-196; J.A. Kelly en J.P. Clinch, 'Temporal variance of revealed preference on-street parking price elasticity', Transport Policy 2009, nr. 4, p. 193-199; M.B.W. Kobus e.a., 'The onstreet parking premium and car drivers choice between street and garage parking', Regional Science and Urban Economics 2013, nr. 2, p. 395-403; J. Simićević e.a., 'Defining parking price based on users attitudes', Transport Policy 2012, nr. 30, p. 70-78; C. Zhang, An empirical evaluation of an on-street parking pricing scheme: A case study in Stockholm inner city, Stockholm: KTY, Royal Institute of Technology 2014.

47. CROW, Parkeren en gedrag: Een totaaloverzicht van alle relevante kennis op het gebied van parkeren en gedrag, p. 43, www.crow.nl/ downloads/documents/kpvv-kennisdocumenten/publicatie-parkeren-en -gedrag-2017?ext=.pdf.

48. J.C.A. de Poorter, T\&C Awb, commentaar op art. 3:2 Awb. gedurende het besluitvormingsproces van standpunt veranderde. ${ }^{49}$

\section{De weg voorwaarts}

Gegeven de bovenstaande analyse van de uitspraken van de rechtbank is de verheldering die het $\mathrm{CBb}$ biedt in het Hengelose hoger beroep meer dan welkom. Allereerst zorgt het College, in aanvulling op de rechtbank, voor een betere bestuursrechtelijke inbedding door het beginsel van zorgvuldige voorbereiding als bedoeld in artikel 3:2 Awb nadrukkelijk te verbinden met de eis van een deugdelijke motivering genoemd in artikel 3:46 Awb. Eveneens sluit de derde eis van het beoordelingskader aan bij het evenredigheidsbeginsel van artikel 3:4 lid 2 Awb.

Vervolgens lijkt het College een grens te stellen aan de onderzoeksplicht van bestuursorganen om uitgezonderd te worden van de verplichting van integrale kostprijs. Wanneer de integrale kostprijs deugdelijk berekend is, maakt een 'aanzienlijk verschil' met commerciële tarieven het volgens het College aannemelijk genoeg dat parkeerders de gemeentelijke parkeervoorzieningen zullen mijden. ${ }^{50}$ Hiervoor lijkt volgens het College dus geen uitgebreid economisch onderzoek naar vraagelasticiteit noodzakelijk te zijn. Het $\mathrm{CBb}$ brengt vervolgens (terecht) de aandacht terug naar geschiktheid en proportionaliteit. In plaats van onderzoek naar gedragseffecten van parkeerprijzen is het raadzamer dat een bestuursorgaan vooral onderzoekt in hoeverre bestaande marktpartijen ook in staat zijn beleidsdoelen na te streven, en hoe nadelige effecten op marktpartijen van een besluit beperkt of gecompenseerd kunnen worden.

Het beoordelingskader van het College is daarmee een relevant en toepasbaar handvat voor zowel bestuursorganen als de rechtbank. Hoewel enigszins omfloerst geformuleerd $^{51}$ zijn de cumulatieve eisen van het College zowel voldoende beschermend voor marktpartijen als voldoende uitvoerbaar voor bestuursorganen.

$\mathrm{Nu}$ is het de vraag in hoeverre de uitspraak in het Hengelose hoger beroep verder strekt dan een uitzondering op de verplichting tot in rekening brengen van integrale kosten op grond van het algemeen belang. Geeft deze uitspraak ook voldoende houvast wanneer de andere drie gedragsregels buiten spel worden gezet op basis van algemeen belang? Hier is wellicht een rol weggelegd voor de wetgevende macht, niet alleen in soft lam-instrumenten als de Handleiding Wet Markt en Overheid, maar ook vooral in formele wetgeving.

Een wijziging van de Wet Markt en Overheid is al enige tijd in voorbereiding. Een conceptvoorstel en toelichting werden in september 2017 ter consultatie voorgelegd, maar dit heeft sindsdien niet geresulteerd in een formeel

49. J.C.A. de Poorter, $T \& C$ Awb, commentaar op art. 3:2 Awb.

50. CBb 18 december 2018, ECLI:NL:CBB:2018:660, r.o. 6.1.

51. Vooral voorwaarde 3 wil ik de lezer in originele vorm niet onthouden: 'Indien hij daaraan toekomt, toetst de bestuursrechter vervolgens of het bestuursorgaan, gelet op de betrokken belangen, in redelijkheid heeft kunnen besluiten van zijn bevoegdheid tot het nemen van een besluit als bedoeld in artikel 25h, zesde lid, van de Mw gebruik te maken op de wijze waarop het dat heeft gedaan.' CBb 18 december 2018, ECLI:NL:CBB:2018:660, r.o. 5.3 
wettraject. ${ }^{52}$ Het conceptvoorstel schrapte artikel $25 \mathrm{~h}$ lid 5-6, ten faveure van een nieuw artikel 25ha met een delegatiebepaling in lid 5 om bij AMvB regels te stellen bij het motiveren van een algemeenbelangbesluit. De ontwerptoelichting spreekt vervolgens de verwachting uit dat deze motiveringseisen in een $\mathrm{AMvB}$ zullen omvatten: ${ }^{53}$

1. een beschrijving van de activiteit waarvoor de algemeenbelanguitzondering wordt ingeroepen;

2. een beschrijving van het algemeen belang dat met het besluit wordt gediend;

3. een duiding van de noodzaak om de algemeenbelanguitzondering in te roepen;

4. een beschrijving van de gevolgen van het gebruik van de algemeenbelanguitzondering op ondernemers;

5. een afweging van de noodzaak van afwijking van de gedragsregels op grond van het algemeenbelangbesluit enerzijds, tegenover het effect op het ondernemersbelang anderzijds.

Motiveringseisen 2 en 3 vertonen gelijkenis met voorwaarde 2 van het $\mathrm{CBb}$ : in beide gevallen moet aangetoond worden dat redelijkerwijs sprake is van (het inroepen van algemeen belang). Er is eveneens gelijkenis tussen motiveringseisen 4 en 5 en voorwaarde 3 van het $\mathrm{CBb}$ : beide gevallen zien toe op een ingevoerde en redelijke afweging van belangen. Het voorstel voorziet in enige mate in voorwaarde 1 van het $\mathrm{CBb}$, door in het nieuwe artikel 25 ha lid 3 de uniforme openbare voorbereidingsprocedure van afdeling 3:4 Awb expliciet van toepassing te verklaren op een algemeenbelangbesluit.

Er lijkt aldus weinig licht te zitten tussen het conceptvoorstel voor een herziene Wet Markt en Overheid en de uitspraak van het $\mathrm{CBb}$. Het probleem is echter dat een formeel wettraject nog niet in zicht is. Totdat een wetsvoorstel met deze motiveringseisen wordt ingediend, zal de rechterlijke macht aan zet blijven bij het afbaken van de algemeenbelanguitzondering uit de Wet Markt en Overheid. Met dank aan het CBb bestaat er nu een werkbaar kader voor de rechter in eerste aanleg.

\section{Conclusie}

In deze annotatie besprak ik de recente jurisprudentie over de mogelijkheid van bestuursorganen om hun economische activiteiten uit te zonderen van een gedragsregel uit de Wet Markt en Overheid, te weten de verplichting tot doorrekenen van integrale kosten.

De Rechtbank Rotterdam is, mijns inziens, in haar 'parkeerberoepen' enigszins doorgeschoten in de vorm van onderzoek die noodzakelijk was ter voorbereiding op een algemeenbelangbesluit. Hoewel de rechtbank terecht de beoordelingsruimte van bestuursorganen bij het vaststellen van algemeen belang ingeperkt heeft, lag de lat nu wel erg hoog. Het uitgebreide vervoerseconomische onderzoek dat noodzakelijk leek te zijn om een vaststellingsbesluit te motiveren is beperkt uitvoerbaar, zeker voor een kleine gemeente. Het $\mathrm{CBb}$ heeft daarom terecht meer nadruk gelegd op het proces: is de voorbereiding van een bestuursorgaan deugdelijk genoeg om beleidskeuzes aannemelijk te maken, is een ingreep ten behoeve van het algemeen belang wel strikt noodzakelijk, en heeft het bestuursorgaan een redelijke belangenafweging gemaakt? Dit kan gezien worden als een uitbreiding en nadere toelichting van de weg die het $\mathrm{CBb}$ inzette in het Zoetermeerse hoger beroep uit 2016. ${ }^{54}$ Waar Zoetermeer de 'vloer' biedt, is Hengelo nu het plafond.

Met deze cumulatieve voorwaarden als maatstaf kunnen zowel bestuursorganen als de rechtbank voorlopig vooruit in zaken waarin een gemeente meent goede redenen te hebben waarom zij de integrale kostprijs van de betrokken activiteit niet in rekening kan brengen - bij afwezigheid van richting vanuit de wetgever. Zulks zou idealiter opgenomen worden in het aangekondigde formele wetgevingstraject.
52. Wetsvoorstel wijziging markt en overheid, concentratietoezicht en privaatrechtelijke handhaving (1 september 2017), www.internet consultatie.nl/wijzigingmarktenoverheid.

53. Wetsvoorstel wijziging markt en overheid, concentratietoezicht en privaatrechtelijke handhaving, ontwerptoelichting, p. 9.
54. CBb 21 december 2016, ECLI:NL :CBB:2016:414. 